Review

\title{
Determinants of health-related quality of life in patients with small cell lung cancer: a systematic PubMed review and meta-analysis
}

\author{
Aristomenis Kossioris ${ }^{1}$, Thaleia Karousi ${ }^{2}$ \\ ${ }^{1}$ University of Patras Medical School, Patras, Greece \\ ${ }^{2}$ General-Maternity District Hospital "Helena Venizelou", Athens, Greece
}

Received 16 November 2015, Accepted 18 December 2015

(C) 2015, Kossioris A., Karousi T.

(C) 2015, Russian Open Medical Journal

Abstract: Objective - Symptoms of small cell lung cancer (SCLC), along with the side-effects of treatment interventions (e.g. nausea and vomiting due to cytotoxic drugs), are supposed to influence negatively the health-related quality of life (HRQoL) of the patients. An understanding of the determinants of SCLC patients' HRQoL could help health professionals in clinical decision making, screening and prediction of health outcomes. The aim of this review was to identify the health-related quality of life determining factors of patients with SCLC.

Methods - A literature review in the PubMed database was conducted in relation to the clinical and sociodemographic determinants of SCLC patients' HRQoL. The extraction and evaluation of the studies was carried out, according to preset criteria, by two reviewers who worked independently.

Results - Thirty-three publications were detected four of which met the inclusion criteria. The majority of the included studies were randomized trials. By the multivariate statistical analysis it was detected that negative influence on SCLC patients' HRQoL had the female gender (Wald Chi-Square $=7.86, p=0.005$ ), the quite a bit or very much tiredness $\left(\chi^{2}=28.54, p<0.001\right)$, the walking difficulty $\left(\chi^{2}=31.80\right.$, $p<0.001)$ and the presence of dyspnea $\left(\chi^{2}=47.52, p<0.001\right)$.

Conclusions - Health professionals could pay more attention to the management of cancer-related fatigue and dyspnea as well as to the enhancement of patients' mobility through low-impact exercise programs or appropriate assistive devices.

Keywords: determinants, quality of life, small cell lung cancer

Cite as Kossioris A, Karousi T. Determinants of health-related quality of life in patients with small cell lung cancer: a systematic PubMed review and metaanalysis. Russian Open Medical Journal 2016; 5: e0104.

Correspondence to Aristomenis Kossioris. Address: 43 Avgis Street, 14121, Iraklio Attikis, Athens, Greece. Phone: +302102820895 . Fax: +30210283332.

E-mail: akossioris@gmail.com

\section{Introduction}

Thirteen to fifteen percent of all lung cancer cases worldwide, are of small cell type (small cell lung cancers, SCLCs) with the median survival time, without any treatment, to be between two and four months $[1,2]$. SCLC, like the non-small lung cancers, is strongly associated with tobacco smoking $[2,3]$. The decrease of tobacco use in recent years led to a respective decrease of the overall incidence of the disease. However, because of the last decades tobacco use expanding among women, the incidence of SCLC in this subgroup has been increased $[4,5]$.

Symptoms of SCLC, along with the side-effects of treatment interventions (e.g. nausea and vomiting due to cytotoxic drugs), are supposed to influence negatively the health-related quality of life (HRQoL) of the patients [6-8].

The HRQoL concept was developed for meeting the need of measuring the subjective perception of a person's health. The World Health Organization (WHO), in 1948, influenced by the opinions of Sigerist $[9,10]$ defined health as "a state of complete physical, mental and social well-being and not merely the absence of disease or infirmity" $[9,11]$. This evolvement emerged the need of measuring the physical, mental and social well-being, concepts which are related to the subjective perception of the individual and are beyond, and many times superior, than the measuring ability of the biomedical indicators. For fulfilling the above need the concept of Health-Related Quality of Life was developed [12].

The HRQoL of SCLC patients has not been well investigated yet [8]. An understanding of the determinants of SCLC patients' HRQoL could help health professionals in clinical decision making, screening and prediction of health outcomes.

The aim of this review was to identify the health-related quality of life determining factors of patients with small cell lung cancer.

\section{Material and Methods}

Search Strategy

This review was conducted by searching in the electronic database PubMed for the period 1991 to June 2015. PubMed is considered the optimal tool in health sciences electronic research [13]. 
Table 1. Summary of the studies included in the review

\begin{tabular}{|c|c|c|c|c|}
\hline Study & Country & Sample & Research design & Measurement instrument \\
\hline Bergman et al. [6] & Sweden & $\begin{array}{l}62 \text { patients with SCLC undergoing } \\
\text { chemotherapy }\end{array}$ & Randomized trial & SIP, HAD \\
\hline Hürny et al. [7] & Switzerland & $\begin{array}{l}127 \text { patients with SCLC undergoing } \\
\text { chemotherapy }\end{array}$ & Randomized trial & $\begin{array}{l}\text { EORTC QL questionnaire, Bf-S } \\
\text { well-being scale, LASA } \\
\text { general well-being scale }\end{array}$ \\
\hline Chen et al. [8] & China & 223 patients with SCLC & Analytical, retrospective, case-control & $\begin{array}{l}\text { LCSS, LASA, ECOG-PS, } \\
\text { Appetite change since } \\
\text { diagnosis item }\end{array}$ \\
\hline Wolfson et al. [14] & USA & $\begin{array}{l}265 \text { patients with LD SCLC } \\
\text { undergoing radiation therapy }\end{array}$ & Randomized trial & QLQ-C $30, B N 20$ \\
\hline
\end{tabular}

SIP, sickness impact profile; HAD, hospital anxiety and depression scale; QLQ-C30, european organization for research and treatment of cancer (EORTC) quality of life questionnaire; Bf-S, befindlichkeits-skala; LASA, linear-analogue self-assessment scale; LCSS, lung cancer symptom scale; ECOG-PS, eastern cooperative oncology group performance status; BN20, brain cancer module 20 .

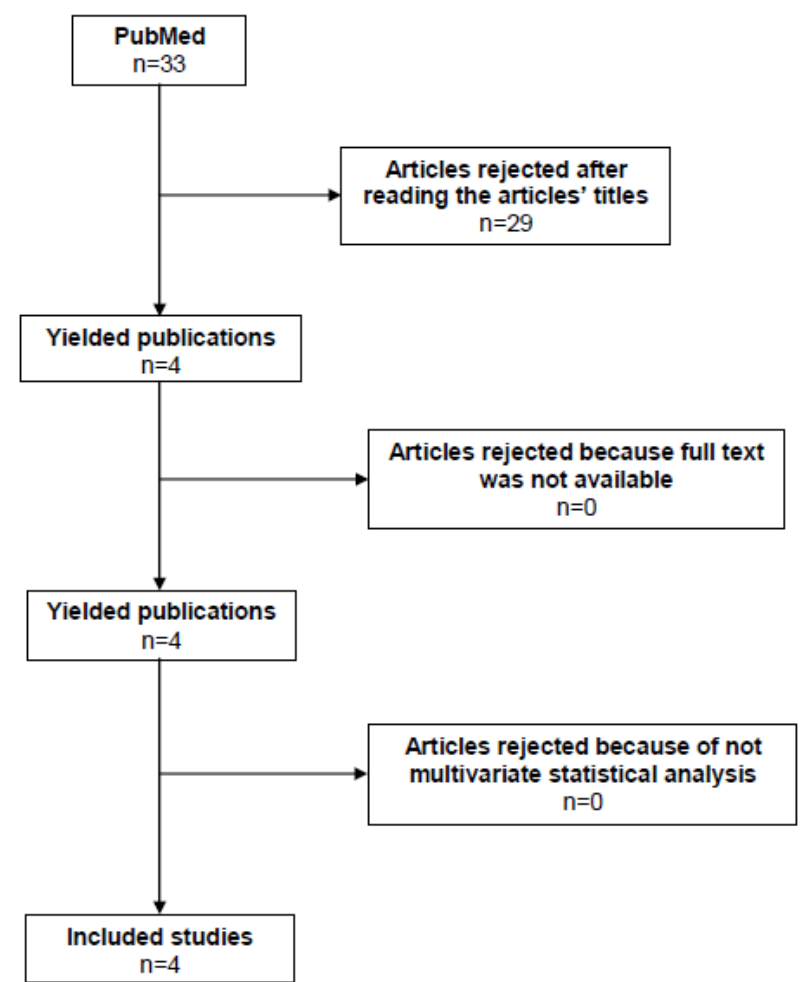

Figure 1. Flow chart - Review process

The literature search was performed using the following string of terms: (()("small cell"[Title] OR "oat cell"[Title] OR "smallcell"[Title] OR "oat-cell"[Title])) AND ("lung cancer"[Title] OR "carcinoma"[Title])) AND "quality of life"[Title]) AND ("multivariate"[Title/Abstract] OR "multivariable"[Title/Abstract] OR "regression"[Title/Abstract] OR "ANOVA"[Title/Abstract]). The terms "multivariate", "multivariable", "regression" and "ANOVA" were used, with respect to the "Title/Abstract" search criterion, for identifying studies with multivariate analysis.

\section{Eligibility Criteria}

The selection of the studies conducted by two reviewers working independently (A. Kossioris, T. Karousi). Firstly, the articles which yielded through the literature search were evaluated, through reading of the articles' titles, and the related to the purpose of the review primary studies were chosen. Afterwards, at the second phase of the selection process, a review of the full text of the publications was taken place (Figure 1).

For including a study in the review, the following criteria were set:

- Articles written in English language.

- Reference population: Persons with SCLC or LD SCLC.

- Outcome: The health-related quality of life measured by a reliable and valid instrument.

- Determinants: Factors concerning the health-related quality of life.

- Statistical analysis: Articles with multivariate analysis and

- Articles published in peer reviewed journals.

\section{Data Extraction}

The data which retrieved from the studies included in the review, came along after consensus of reviewers. The name of the study first author, measurement instrument, sample size, research design, gender, educational level, marital status, fatigue presence or absence, coughing presence or absence, walking capacity, awareness of drive to breath (increased or decreased drive), working status and smoking status were summarized (Tables 1 and 2).

\section{Data Analysis}

The Likelihood Ratio Chi-Square test was used for assessing the value of performing a diagnostic test and evaluate the goodness of fit of our model $\left(x^{2}=221.249, p<0.001\right)$. The dependent variable of the linear model was the quality of life measurements mean score which was extracted of each study separately and is calculated massively.

\section{Results}

After the selection process (Figure 1) four studies were included in the review, three randomized trials and one of analytic, retrospective, case-control research design.

The studies of Bergman et al. [6] from Sweden, Hürny et al. [7] from Switzerland and Wolfson et al. [14] from the USA were the randomized trials, while the study of Chen et al. [8] from China was of the analytical, retrospective, case-control design (Table 1).

By the multivariate statistical analysis it was detected that more positive impact on SCLC patients' HRQoL had the high school, and below, level of education (Wald Chi-Square $=10.10, p=0.001$ ), the substantial presence of coughing (quite a bit or very much) $\left(\chi^{2}=80.86, p<0.001\right)$ and the smoking habit $\left(\chi^{2}=12.29, p<0.001\right)$. 
Table 2. Descriptive table of patients' characteristics

\begin{tabular}{|c|c|c|c|}
\hline Variables & & $N$ & Percentage \\
\hline \multirow[t]{4}{*}{ Gender } & Male & 300 & 55.2 \\
\hline & Female & 206 & 37.9 \\
\hline & Missing values & 37 & 6.8 \\
\hline & Total & 543 & 100 \\
\hline \multirow[t]{4}{*}{ Educational level } & $<$ high school & 21 & $3.9^{-}$ \\
\hline & $>$ high school & 35 & 6.4 \\
\hline & Missing values & 487 & 89.7 \\
\hline & Total & 543 & 100 \\
\hline \multirow[t]{4}{*}{ Marital status } & Married & 36 & 6.6 \\
\hline & Single & 23 & 4.2 \\
\hline & Missing values & 484 & 89.1 \\
\hline & Total & 543 & 100 \\
\hline \multirow[t]{3}{*}{ Fatigue } & Quite a bit or very much & 371 & 68.3 \\
\hline & Not at all or a little & 172 & 31.7 \\
\hline & Total & 543 & 100 \\
\hline \multirow[t]{3}{*}{ Coughing } & Quite a bit or very much & 379 & 69.8 \\
\hline & Not at all or a little & 164 & 30 \\
\hline & Total & 543 & 100 \\
\hline \multirow[t]{3}{*}{ Walk difficulty } & Yes & 230 & 42.4 \\
\hline & No & 313 & 57.6 \\
\hline & Total & 543 & 100 \\
\hline \multirow[t]{3}{*}{ Dyspnea } & Yes & 364 & 67.0 \\
\hline & No & 179 & 33.0 \\
\hline & Total & 543 & 100 \\
\hline \multirow[t]{3}{*}{ Work } & Light work & 378 & 69.6 \\
\hline & Unable to work and worse & 165 & 30.4 \\
\hline & Total & 543 & 100 \\
\hline \multirow[t]{5}{*}{ Smoking status } & Never smoker & 69 & 12.7 \\
\hline & Former smoker & 160 & 29.5 \\
\hline & Current smoker & 118 & 21.7 \\
\hline & Missing values & 196 & 36.1 \\
\hline & Total & 543 & 100 \\
\hline
\end{tabular}

Table 3. SCLC patients' HRQoL determining factors

\begin{tabular}{|c|c|c|c|c|}
\hline \multicolumn{2}{|c|}{ Factors } & $B$ & Wald Chi-Square & $P$ value \\
\hline \multirow[t]{2}{*}{ Gender } & Male & -0.18 & 5.21 & 0.022 \\
\hline & Female & -0.23 & 7.86 & 0.005 \\
\hline \multirow{2}{*}{$\begin{array}{l}\text { Educational } \\
\text { level }\end{array}$} & $<$ high school & 0.80 & 10.09 & $<0.001$ \\
\hline & $>$ high school & 0.72 & 10.32 & $<0.001$ \\
\hline \multirow{2}{*}{$\begin{array}{l}\text { Marital } \\
\text { status }\end{array}$} & Married & 0.034 & 0.02 & 0.890 \\
\hline & Single & 0.032 & 0.02 & 0.880 \\
\hline Fatigue & $\begin{array}{l}\text { Quite a bit or } \\
\text { very much }\end{array}$ & -0.34 & 28.54 & $<0.001$ \\
\hline Coughing & $\begin{array}{l}\text { Quite a bit or } \\
\text { very much }\end{array}$ & 0.56 & 80.86 & $<0.001$ \\
\hline $\begin{array}{l}\text { Walk } \\
\text { difficulty }\end{array}$ & Yes & -0.32 & 31.80 & $<0.001$ \\
\hline \multirow{2}{*}{$\begin{array}{l}\text { Dyspnea } \\
\text { Work }\end{array}$} & Yes & -0.43 & 47.52 & $<0.001$ \\
\hline & Light work & 0.01 & 0.02 & 0.900 \\
\hline \multirow{3}{*}{$\begin{array}{l}\text { Smoking } \\
\text { status }\end{array}$} & Never smoker & -0.7 & 1.24 & 0.270 \\
\hline & Former smoker & 0.18 & 4.44 & 0.035 \\
\hline & Current smoker & 0.20 & 12.29 & $<0.001$ \\
\hline
\end{tabular}

On the other hand, negative influence on SCLC patients' HRQoL had the female gender $\left(\chi^{2}=7.86, p=0.005\right)$, the quite a bit or very much tiredness $\left(\chi^{2}=28.54, p<0.001\right)$, the walking difficulty $\left(\chi^{2}=31,80, p<0,001\right)$ and the presence of dyspnea $\left(\chi^{2}=47.52\right.$, $p<0.001$ ) (Tables 2 and 3).

\section{Discussion}

Symptoms of SCLC, in company with the side-effects of the cytotoxic medications, are supposed to affects negatively the HRQoL of the patients [6-8]. An understanding of the determining factors of SCLC patients' HRQoL could guide health professionals in clinical decision making, screening and prognosis of health outcomes.

The most significant finding of this review, was the fact that dyspnea influences negatively the HRQoL. Dyspnea is a common symptom among lung cancer patients $[15,16]$. According to the study done by Smith et al. [17], patients with high dyspnea scores had lower QoL ( $p=0.040)$. Additionally, the cross-sectional study of Sarna et al. demonstrated that dyspnea induces risk for decreased physical and social aspects of QoL [18].

In regard to the educational level, it was found that the high school, and below, level of education had more positive impact on HRQoL ( $B=0.795)$. This finding is, generally, in contrast with the literature. A Spanish study done by Regidor et al. [19] showed that perceived health status diminishes with decreasing educational level, with the exception of women with secondary education who had a higher mean scoring than women with higher education on diverse health dimensions. Furthermore, concordantly to Mielck et al. [20], low educational status groups are encountered with a double burden. Nevertheless, the outlandish finding of our study could be justified by the many missing values of the massive sample $(n=487)$.

From the statistical analysis, it was detected that the quite a bit or very much coughing had affirmative effect on HRQoL. This finding is in contrast with the literature [21], in which coughing is considered an afflicting factor for life's quality. However, this could be explained from the symptoms characteristics of the Chen et al. study [8], the main research from which the coughing data were retrieved. Chen et al. [8] found that the lowest coughing mean score (66.4) took place in the fourth follow-up year. Furthermore, in the same study [8] appears to be a proneness that as the years pass, the coughing scores decreases.

As for the smoking status, it was discovered that smoking habit has positive impact on HRQoL. This finding is also contradictory with the literature [22-26]. Smoking has been repeatedly associated with lower QoL. Nonetheless, this discrepancy could be explained by the fact that there were many missing values in the review sample ( $\mathrm{n}=196)$.

In relation to the gender, the female gender had negative effect on HRQoL. This detection is in agreement with the study of Pud et al. [27] in which female cancer patients reported significantly lower psychological dimension of QoL than their male counterparts $(p=0.009)$.

With regard to fatigue presence or absence, the quite a bit or very much tiredness was detected to be adversely associated with HRQoL. This finding is concordant with the literature $[28,29]$. Fatigue has been acknowledged as a common and distressing symptom in cancer.

With respect to walking capacity, walking difficulty had negative impact on HRQoL. This detection is consonant to the recent study of Bindawas et al. [30] in which increased lower extremity performance was associated with slower rates of decrease in participants' physical and mental HRQoL.

As for the awareness of drive to breath, it was detected that the presence of dyspnea had adverse influence on HRQoL. The 
aforementioned finding is in agreement with the study done by Smith et al. [17] in which patients with high dyspnea scores had lower QoL ( $p=0.040)$ such as with the study of Gupta et al. [31] which demonstrated that every ten unit increase in dyspnea score was statistically significantly associated with $0.81,0.16,0.47$, and 0.47 unit decline in Ferrans and Powers [32] Quality of Life Index (QLI).

\section{Conclusion}

Health professionals could pay more attention to the management of cancer-related fatigue and dyspnea as well as to the enhancement of patients' mobility through low-impact exercise programs or appropriate assistive devices.

\section{Conflict of Interest}

The authors declare that there are no conflicts of interest. The review was self-funding.

\section{References}

1. Rosti G, Bevilacqua G, Bidoli P, Portalone L, Santo A, Genestreti G. Small cell lung cancer. Ann Oncol 2006; 17(suppl 2): ii5-ii10. (doi: 10.1093/annonc/mdj910)

2. Simon GR, Wagner H. Small cell lung cancer. Chest 2003; 123(1 Suppl): 259S-271S. (PMID: 12527584)

3. Johnson BE, Crawford J, Downey RJ, Ettinger DS, Fossella F, Grecula JC. Small cell lung cancer clinical practice guidelines in oncology. J Natl Compr Canc Netw 2006; 4(6): 602-622. (PMID: 16813728)

4. Govindan R, Page N, Morgensztern D, Read W, Tierney R, Vlahiotis A, et al. Changing epidemiology of small-cell lung cancer in the United States over the last 30 years: analysis of the surveillance, epidemiologic, and end results database. J Clin Oncol 2006; 24(28): 4539-4544. (PMID: 17008692) (doi: 10.1200/JCO.2005.04.4859)

5. Kalemkerian GP, Akerley W, Bogner P, Borghaei H, Chow LQ, Downey RJ, et al. Small cell lung cancer. J Natl Compr Canc Netw 2013; 11(1): 78-98. (PMID: 23307984)

6. Bergman B, Sullivan $M$, Sörenson S. Quality of life during chemotherapy for small cell lung cancer: I. An evaluation with generic health measures. Acta Oncol 1991; 30(8): 947-957. (PMID: 1663774).

7. Hürny C, Bernhard J, Joss R, Schatzmann E, Cavalli F, Brunner K, et al. "Fatigue and malaise" as a quality-of-life indicator in small-cell lung cancer patients. he Swiss Group for Clinical Cancer Research (SAKK). Support Care Cancer 1993; 1(6): 316-320. (PMID: 8156249)

8. Chen J, Qi Y, Wampfler JA, Jatoi A, Garces YI, Busta AJ, et al. Effect of cigarette smoking on quality of life in small cell lung cancer patients. Eur J Cancer 2012; 48(11): 1593-1601. (doi: 10.1016/j.ejca.2011.12.002) (PMID: 22244802)

9. Tountas Y. Society and Health. Athens: Odysseus, 2000: 30-31.

10. Terris M. The contributions of Henry E. Sigerist to health service organization. Milbank Mem Fund Q Health Soc 1975; 53(4): 489-530. (PMID: 765888)

11. World Health Organization. WHO definition of Health. Available at: http://www.who.int/about/definition/en/print.html. Assecced July 19 2014.

12. Tountas $Y$, Sarafis P. The health of the Greek population. Athens: Papazisis; 2009; $161 \mathrm{p}$.

13. Falagas ME, Pitsouni El, Malietzis GA, Pappas G. Comparison of PubMed, Scopus, web of science, and Google scholar: strengths and weaknesses. FASEB J 2008; 22(2): 338-342. (PMID: 17884971)

14. Wolfson A.H., Bae K., Komaki R., Meyers C, Movsas B, Le Pechoux C, et al. Primary analysis of a phase II randomized trial Radiation Therapy Oncology Group (RTOG) 0212: impact of different total doses and schedules of prophylactic cranial irradiation on chronic neurotoxicity and quality of life for patients with limited-disease small-cell lung cancer. Int J Radiat Oncol Biol Phys 2011; 81: 77-84. (doi: 10.1016/j.ijrobp.2010.05.013) (PMID: 20800380)

15. Reuben DB, Mor V. Dyspnea in terminally ill cancer patients. Chest 1986; 89(2): 234-236. (PMID: 3943383)

16. Billings JA. Outpatient management of advanced cancer: symptom control, support, and hospice-in-the-home. Lippincott, 1985; 81 p.

17. Smith EL, Hann DM, Ahles TA, Furstenberg CT, Mitchell TA, Meyer L, et al. Dyspnea, anxiety, body consciousness, and quality of life in patients with lung cancer. J Pain Symptom Manage 2001; 21(4): 323-329. (PMID: 11312047)

18. Sarna L, Evangelista L, Tashkin D, Padilla G, Holmes C, Brecht ML, Grannis F. Impact of respiratory symptoms and pulmonary function on quality of life of long-term survivors of non-small cell lung cancer. Chest 2004; 125(2): 439-445. (PMID: 14769722)

19. Regidor E, Barrio G, de la Fuente L, Domingo A, Rodriguez C, Alonso J. Association between educational level and health related quality of life in Spanish adults. J Epidemiol Community Health 1999; 53(2): 75-82. (PMCID: PMC1756832)

20. Mielck A, Reitmeir P, Vogelmann M, Leidl R. Impact of educational level on health-related quality of life (HRQL): results from Germany based on the EuroQol 5D (EQ-5D). Eur J Public Health 2013; 23(1): 4549. (doi: 10.1093/eurpub/ckr206) (PMID: 22434205)

21. Molassiotis A, Smith JA, Bennett MI, Blackhall F, Taylor D, Zavery B, et al. Clinical expert guidelines for the management of cough in lung cancer: report of a UK task group on cough. Cough 2010; 6: 9. (doi: 10.1186/1745-9974-6-9) (PMID: 20925935)

22. Taira DA, Seto TB, Ho KK, Krumholz HM, Cutlip DE, Berezin R, et al. Impact of smoking on health-related quality of life after percutaneous coronary revascularization. Circulation 2000; 102(12): 1369-1374. (PMID: 10993854) (doi: 10.1161/01.CIR.102.12.1369)

23. Heikkinen $\mathrm{H}$, Jallinoja $\mathrm{P}$, Saarni SI, Patja $\mathrm{K}$. The impact of smoking on health-related and overall quality of life: a general population survey in Finland. Nicotine Tob Res 2008; 10(7): 1199-1207. (doi: 10.1080/14622200802163142) (PMID: 18629730)

24. Piper ME, Kenford S, Fiore MC, Baker TB. Smoking cessation and quality of life: changes in life satisfaction over 3 years following a quit attempt. Ann Behav Med 2012; 43(2): 262-270. (PMID: 22160762) (doi: 10.1007/s12160-011-9329-2)

25. Toghianifar N, Najafian J, Pooya A, Rabiei K, Eshrati B, Anaraki J, Sarrafzadegan N. Association of smoking status with quality of life in a cross-sectional population-based sample of iranian adults Isfahan healthy heart program. Asia Pac J Public Health 2012; 24(5): 786-794. (doi: 10.1177/1010539511403800) (PMID: 21490110)

26. Goldenberg M, Danovitch I, IsHak WW. Quality of life and smoking. Am $J$ Addict 2014; 23(6): 540-562. (PMID: 25255868) (doi: 10.1111/j.15210391.2014.12148.x)

27. Pud D. Gender differences in predicting quality of life in cancer patients with pain. Eur J Oncol Nurs 2011; 15(5): 486-491. (doi: 10.1016/j.ejon.2010.12.005) (PMID: 21256079)

28. Mock V, Pickett M, Ropka ME, Muscari Lin E, Stewart KJ, Rhodes VA, et al. Fatigue and quality of life outcomes of exercise during cancer treatment. Cancer Pract 2001; 9(3): 119-127. (PMID: 11879296) (doi: 10.1046/j.1523-5394.2001.009003119.x)

29. Wu HS, Davis JE. Definition, prevalence and characteristics of sudden exhaustion: a possible syndrome of fatigue in cancer? Support Care Cancer 2013; 21(2): 609-617. (doi: 10.1007/s00520-012-1555-z) (PMID: 22893482)

30. Bindawas SM, Al Snih S, Ottenbacher AJ, Graham J, Protas EE, Markides KS, Ottenbacher KJ. Association between lower extremity performance and health-related quality of life in elderly Mexican Americans. J Aging Health 2015; 27(6): 1026-1045. (doi: 10.1177/0898264315572115) (PMID: 25804900)

31. Gupta D, Lis CG, Grutsch JF. The relationship between dyspnea and patient satisfaction with quality of life in advanced cancer. Support 
Care Cancer 2007; 15(5): 533-538. (doi: 10.1007/s00520-006-0178-7) (PMID: 17120067)

32. Ferrans CE, Powers MJ. Quality of life index: development and psychometric properties. ANS Adv Nurs Sci 1985; 8(1): 15-24. (PMID: 3933411)

Authors:

Aristomenis Kossioris - RN, MSc, PhDc, University of Patras Medical School, Patras, Greece.

Thaleia Karousi - Biostatistician, MSc, General-Maternity District Hospital

"Helena Venizelou", Athens, Greece. 